\title{
PENGARUH KINERJA KEUANGAN PEMERINTAH DAERAH TERHADAP PERTUMBUHAN EKONOMI PADA PEMERINTAH KOTA/KABUPATEN DI RIAU
}

\author{
Ade Pipit Fatmawati, Delia Syafitri \\ Program Studi D4 Akuntansi Keuangan, Politeknik Pos Indonesia \\ adepipitfatmawati@poltekpos.ac.id, deliasyafitri74@gmail.com
}

\begin{abstract}
ABSTRAK
Pertumbuhan ekonomi merupakan suatu gambaran hasil yang dikerjakan oleh pemerintah untuk meningkatkan kesejahteraan masyarakat dan sebagai kenaikan pendapatan disuatu daerah. Penelitian ini bertujuan untuk mengetahui pengaruh kinerja keuangan pemerintah daerah terhadap pertumbuhan ekonomi pada pemerintah kota/kabupaten di Riau. Populasi penelitian ini sebanyak 12 pemerintahan, dan sebanyak 40 sampel. Pengambilan sampel menggunakan nonprobability sampling dengan teknik purposive sampling dan data yang digunakan bersumber dari data sekunder. Metode yang digunakan dalam penelitian ini adalah metode kuantitatif. Pengujian hipotesis dari penelitian ini menunjukkan bahwa secara parsial, rasio efektivitas tidak berpengaruh terhadap pertumbuhan ekonomi, dan secara parsial bahwa rasio efesiensi berpengaruh terhadap pertumbuhan ekonomi. Secara simultan bahwa rasio efektivitas dan rasio efesiensi berpengaruh terhadap pertumbuhan ekonomi.
\end{abstract}

Kata Kunci: Rasio Efektivitas, Rasio Efisiensi, Pertumbuhan Ekonomi

\section{ABSTRACT}

Economic growth is a description of the results undertaken by the government to improve the welfare of society and as an increase in income in an area. This study aims to determine the effect of local government financial performance on economic growth in city / district governments in Riau. The population of this research is 12 governments, and as many as 40 samples. Sampling using nonprobability sampling with purposive sampling technique and the data used comes from secondary data. The method used in this research is quantitative method. Hypothesis testing of this study shows that partially, the effectiveness ratio has no effect on economic growth, and partially that the efficiency ratio affects economic growth. Simultaneously, the effectiveness ratio and efficiency ratio affect economic growth.

Keywords: Effectiveness Ratio, Efficiency Ratio, Economic Growth 


\section{PENDAHULUAN}

Negara Indonesia merupakan Negara yang memiliki 34 Provinsi yang terdiri dari kota/kabupaten yang tersebar di Provinsi tersebut. Berdasarkan penerapan otonomi daerah dengan Undang-undang Nomor 23 tahun 2014 tentang pemerintahan daerah yang merupakan hak, wewenang, dan kewajiban daerah otonomi untuk mengatur dan mengurus sendiri urusan pemerintahan dan kepentingan masyarakat setempat sesuai dengan peraturan perundang-undangan yang berlaku salah satunya yaitu untuk pengelolaan keuangan daerah.

Pertumbuhan ekonomi merupakan cara untuk berhasilnya suatu pembangunan ekonomi di suatu daerah. Perekonomian dianggap mengalami pertumbuhan apabila seluruh penggunaan faktor-faktor produksi pada tahun tertentu lebih besar daripada pendapatan riil masyarakat pada tahun sebelumnya. Salah satu indikator yang digunakan untuk mengukur pertumbuhan ekonomi suatu daerah pada periode tertentu adalah tingkat pertumbuhan Produk Regional Domestik Bruto (PDRB).

Dikutip dari Riau, Goriau, pada 10 Februari 2020 mengatakan bahwa "pertumbuhan perekonomian Riau tahun 2019 sebesar 2.84 persen, artinya masih dibawah angka pertumbuhan ekonomi menurut Misfaruddin ternyata Riau berada diposisi paling 'bontot' dimana pertumbuhan ekonomi diwilayah Sumatera yang secara komulatif tumbuh 4,57 persen, menurut Badan Pusat Statistik (BPS) Provinsi Riau lapangan usaha mengalami penurunan yang mengakibatkan pertumbuhan perekonomian Riau mengalami penurunan"

Berdasarkan fenomena di atas bahwa pertumbuhan ekonomi di Riau mengalami penurunan yang diakibatkan oleh beberapa faktor yang berdampak pada beberapa hal. Menurut Muhammad Syukri \& Hinaya (2019:31) Kemajuan daerah sangat dipengaruhi oleh pertumbuhan ekonomi dan jumlah pendapatan daerah yang berdampak pada kesejahteraan masyarakat indikator kesejahteraan pada suatu daerah dipengaruhi oleh jumlah pendapatan daerah. Besarnya pertumbuhan ekonomi dan kemajuan pembangunan daerah. Secara umum pertumbuhan ekonomi dapat diartikan sebagai perkembangan kegiatan dalam perekonomian yang menyebabkan barang dan jasa yang diproduksi dalam masyarakat bertambah dan kemakmuran masyarakat meningkat.

Salah satu tujuan di suatu daerah yaitu terwujudnya kesejahteraan masyarakat dalam hal ini tidak ada kesenjangan di berbagai wilayah atau daerah yang dapat dilihat dari kinerja suatu daerah tersebut hal ini dapat ditunjukan bahwa Penggunaan indikator kinerja sangat penting untuk mengetahui apakah suatu $\mathrm{p}$ rogram kerja telah dilaksanakan secara efisien dan efektif (Mardiasmo, 2018). Menurut Agustina dalam Pramita (2015:9) kinerja 
keuangan daerah merupakan tingkat pencapaian dari suatu hasil kerja di bidang keuangan daerah yang meliputi penerimaan dan belanja daerah dengan menggunakan indikator keuangan yang ditetapkan melalui suatu kebijakan atau ketentuan perundang-undangan selama satu periode anggaran.

Pada hasil penelitian terdahulu, menurut hasil penelitian Greydi Normala Sari, Paulus Kindangen, Tri Oldy Rotinsulu (2016) bahwa rasio kemandirian memiliki pengaruh yang positif dan signifikan terhadap pertumbuhan ekonomi, rasio efesiensi juga berpengaruh positif dan signifikan terhadap pertumbuhan ekonomi, rasio efektivitas tidak berpengaruh terhadap pertumbuhan ekonomi sedangkan rasio ketergantungan berpengaruh negatif dan signifikan hal ini telah sesuai dengan teori Sedangkan hasil penelitian Syamsudin, Bayu Tri Cahya, Syahrina Nurmala Dewi (2015) dengan regresi menunjukkan bahwa variabel kinerja keuangan yaitu rasio independen, secara langsung berpengaruh positif signifikan terhadap pertumbuhan ekonomi, sedangkan rasio efektivitas dan rasio efisiensi secara langsung berpengaruh signifikan terhadap pertumbuhan ekonomi. Di ekonomi pertumbuhan secara langsung berpengaruh positif signifikan terhadap pengangguran dan juga secara langsung berpengaruh positif signifikan terhadap kemiskinan. Untuk menguji secara tidak langsung antar variabel kinerja keuangan pada pengangguran dan pemulihan menunjukkan rasio independen, rasio efektivitas dan rasio efisiensi berpengaruh signifikan terhadap pengangguran dan kemiskinan, sementara efektivitas tidak berpengaruh signifikan terhadap pengangguran dan kemiskinan. Hasil penelitian Kartika Berliani (2016) bahwa kinerja keuangan berpengaruh secara simultan dan berpengaruh positif secara parsial terhadap pertumbuhan ekonomi, kinerja keuangan berpengaruh secara simultan dan berpengaruh positif secara parsial terhadap tingkat kesejahteraan masyarakat. Pertumbuhan ekonomi berpengaruh positif terhadap tingkat kesejahteraan masyarakat. Kinerja keuangan berpengaruh terhadap pertumbuhan ekonomi dan memberikan dampak terhadap tingkat kesejahteraan masyarakat Kabupaten Majalengka.

Dari penjelasan diatas, maka rumusan masalah yang digunakan dalam penelitian ini adalah: 1) Bagaimana Pengaruh Rasio Efektivitas Terhadap Pertumbuhan Ekonomi Pada Pemerintah Kota/Kabupaten di Riau? 2) Bagaimana Pengaruh Rasio Efisiensi Terhadap Pertumbuhan Ekonomi Pada Pemerintah Kota/Kabupaten di Riau? 3) Bagaimana Pengaruh Rasio Efektivitas dan Rasio Efisiensi Terhadap Pertumbuhan Ekonomi Pada Pemerintah Kota/Kabupaten di Riau? 


\section{KAJIAN PUSTAKA}

\section{Kinerja Keuangan Daerah}

Menurut (Mardiasmo, 2017:121) menyatakan bahwa:

"Kinerja keuangan dalam organisasi sektor publik berkaitan dengan prestasi dan akuntabilitas organisasi dan manajemen dalam menghasilkan pelayanan public yang lebih baik. Akuntabilitas yang merupakan salah satu cirri dari terapan good governance bukan hanya sekedar kemampuan begaimana menunjukan bahwa uang public tersebut telah dibelanjakan secara ekonomis, efektif, dan efisien."

\section{Rasio Efektivitas}

Menurut (Kuwatu, 2019:99). Rasio Efektivitas menunjukkan kemampuan pemerintah daerah dalam memobilisasi penerimaan PAD sesuai dengan yang ditargetkan.

\section{Rasio Efisiensi}

(Mahsun, 2016:187) mendefinisikan bahwa "tingkat pengukuran rasio efesiensi memerlukan data-data realisasi biaya untuk dapat memperoleh pendapatan dan data realisasi pendapatan".

\section{Pertumbuhan Ekonomi}

Menurut (Sukirno, 2015:331), menyatakan "pertumbuhan ekonomi diartikan sebagai kemajuan kegiatan dalam perekonomian yang menjadikan barang dan jasa yang diproduksi oleh masyarakat bertambah dan kemakmuran masyarakat akan bertambah".

\section{METODE PENELITIAN}

Metode dari penelitian ini adalah kuantitatif dengan perumusan masalah asosiatif dalam bentuk hubungan sebab akibat (kausal). (Sugiyono, 2017:63-64) mengemukakan bahwa "rumusan masalah asosiatif adalah suatu rumusan masalah penelitian yang bersifat menanyakan hubungan antara dua variabel atau lebih, sedangkan hubungan kausal adalah hubungan yang bersifat sebab akibat. Jadi disini ada variabel independen (variabel yang mempengaruhi) dan dependen (dipengaruhi)".

\section{Teknik Pengumpulan Data}

Pengumpulan data menggunakan sumber sekunder. Dalam penelitian ini, data yang diperoleh dengan cara:

a. Dokumentasi 
Pengumpulan data dengan melihat dokumen-dokumen, seperti dengan mengakses situs resmi Badan Pusat statistic (BPS) situs resmi setiap pemerintah kota/kabupaten yang berkaitan dengan data laporan keuangan dan laju pertumbuhan PDRB pemerintahkota/kabupaten yang terkait..

\section{Teknik Sampling}

\section{Populasi}

Pemerintahan Kota/Kabupaten di Riau tahun 2016-2019, yaitu sebanyak 12 Pemerintahan merupakan populasi dalam penelitian ini.

\section{Sampel}

Sampel yang diambil dengan metode Nonprobability Sampling yaitu teknik purposive sampling. Menurut Sekaran dan Bougie (Sugiyono, 2017:67), “purposive sampling dapat memberikan sampel yang terbatas pada jenis tertentu yang dapat memberikan informasi yang diinginkan, mungkin karena mereka adalah salah satu yang memiliki atau memenuhi kriteria sampel yang ditentukan oleh peneliti”. Berikut hasil purposive sampling:

Tabel 1. Tabel Kriteria

\begin{tabular}{|c|l|c|}
\hline No. & \multicolumn{1}{|c|}{ Kriteria } & Jumlah \\
\hline 1. & Pemerintah Kota/Kabupaten yang terletak di Provinsi Riau & 12 \\
\hline 2. & $\begin{array}{l}\text { Pemerintah Kota/Kabupaten yang tidak menerbitkan laporan Laju } \\
\text { pertumbuhan PDRB dan Laporan keuangan selama periode 2016-2019 }\end{array}$ & $(2)$ \\
\hline 3. & $\begin{array}{l}\text { Pemerintah Kota/Kabupaten yang menerbitkan laporan Laju pertumbuhan } \\
\text { PDRB dan Laporan keuangan }\end{array}$ & 10 \\
\hline Jumlah data yang dijadikan sampel yaitu 10 x 4 Tahun & 40 \\
\hline
\end{tabular}

Sumber: Diolah Penulis (2020)

\section{HASIL DAN PEMBAHASAN}

\section{Uji Normalitas Data}

Tabel 2. Hasil Uji Normalitas Kolmogorov-Smirnov 


\begin{tabular}{llr} 
& & Unstandardized Residual \\
\hline $\mathrm{N}$ & & 40 \\
\hline Normal Parameters & Mean & .0000000 \\
\cline { 2 - 3 } & Std. Deviation & 1894487.52372463 \\
\hline Most Extreme Differences & Absolute & .099 \\
\cline { 2 - 3 } & Positive & .091 \\
\cline { 2 - 3 } & Negative & .099 \\
\hline Test Statistic & & .099 \\
\hline Asymp. Sig. (2-tailed) & & $.200^{\text {c., }}$ \\
\hline
\end{tabular}

a. Test distribution is Normal.

b. Calculated from data.

c. Lilliefors Significance Correction.

d. This is a lower bound of the true significance.

Sumber: Hasil Pengolahan Data Dengan IBM SPSS Statistics 25

Berdasarkan tabel 2 diatas, dapat diketahui bahwa besarnya nilai Sig (probabilitas) yaitu $0,200>0,05$. Sehingga dapat disimpulkan bahwa model regresi dalam penelitian ini berdistribusi normal.

\section{Korelasi Product Moment}

Berikut tabel hasil korelasi product moment:

\section{Tabel 3. Hasil Korelasi Product Moment}

\begin{tabular}{|c|c|c|c|c|}
\hline \multicolumn{5}{|c|}{ Correlations } \\
\hline & & Rasio Efektivitas & Rasio Efisiensi & $\begin{array}{l}\text { Pertumbuhan } \\
\text { Ekonomi }\end{array}$ \\
\hline \multirow[t]{3}{*}{ Rasio Efektivitas } & Pears on Correlation & 1 & -.091 & -.270 \\
\hline & Sig. (2-tailed) & & .577 & .092 \\
\hline & $\mathrm{N}$ & 40 & 40 & 40 \\
\hline \multirow[t]{3}{*}{ Rasio Efisiensi } & Pears on Correlation & -.091 & 1 & .432 \\
\hline & Sig. (2-tailed) & .577 & & .000 \\
\hline & $\mathrm{N}$ & 40 & 40 & 40 \\
\hline \multirow[t]{3}{*}{ PertumbuhanEkonomi } & Pears on Correlation & -.270 & .432 & 1 \\
\hline & Sig. (2-tailed) & .092 & .000 & \\
\hline & $\mathrm{N}$ & 40 & 40 & 40 \\
\hline
\end{tabular}

\section{Sumber: Hasil Pengolahan Data Dengan IBM SPSS Statistics 25}

Besaran angka korelasi antara variabel rasio efektivitas terhadap pertumbuhan ekonomi (Y) memiliki nilai -0,270 yang berarti pada tingkat hubungan rendah karena berada pada interval koefisien 0,20-0,399. Untuk angka korelasi antara variabel rasio 
efisiensi terhadap pertumbuhan ekonomi (Y) memiliki nilai 0,432 yang berarti pada tingkat hubungan sedang karena berada pada interval koefisien 0,40-0,599.

\section{Korelasi Ganda}

Tabel 4. Hasil Korelasi Ganda

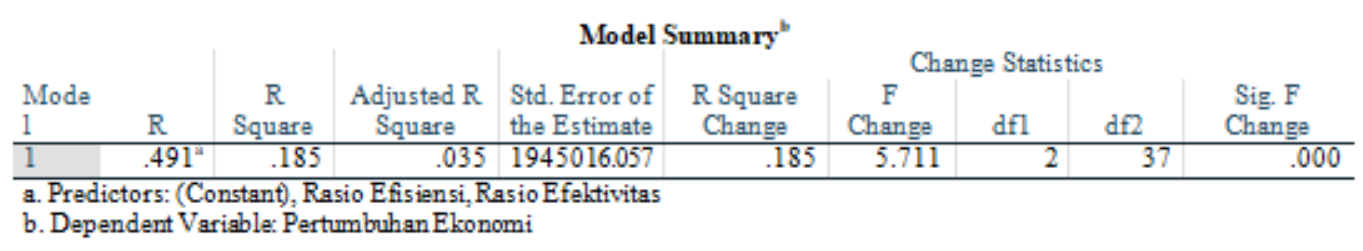

\section{Sumber: Hasil Pengolahan Data Dengan IBM SPSS Statistics 25}

Dari hasil pengolahan data di atas, dapat diketahui bahwa besarnya hubungan antara rasio efektivitas dan rasio efisiensi secara bersama-sama terhadap pertumbuhan ekonomi dari nilai $\mathrm{R}$ adalah 0,491 . Hal tersebut menunjukkan bahwa rasio efektivitas dan rasio efisiensi secara bersama-sama atau simultan memiliki pengaruh yang sedang.

\section{Analisis Regresi Ganda}

Persamaan regresi berganda dalam penelitian ini dapat ditentukan berdasarkan hasil tabel coefficients di kolom unstandardized coefficients bagian B berikut:

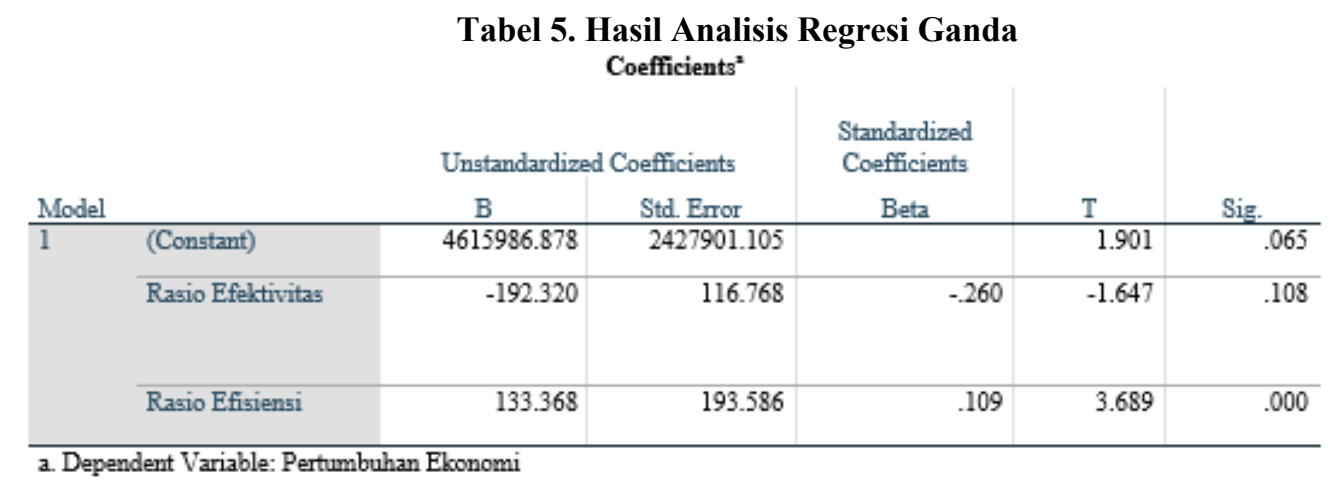

\section{Sumber: Hasil Pengolahan Data Dengan IBM SPSS Statistics 25}

Berdasarkan tabel 4.8 pada kolom unstandardized coefficients bagian B diperoleh persamaan analisis regresi ganda sebagai berikut:

Pertumbuhan Ekonomi $=4615986,878+(-0,192,320)$ Rasio Efektivitas $+133,368$ Rasio Ef isiensi

Dari persamaan regresi ganda diatas, maka dapat diambil kesimpulan: 
a. Bahwa nilai konstanta (a) sebesar 4615986,878 , artinya jika nilai variabel X1: rasio efektivitas dan X2: rasio efisiensi nilainya sama dengan nol (0), maka variabel pertumbuhan ekonomi (Y) nilainya adalah 4615986,878.

b. Koefisien regresi variabel rasio efektivitas (X1) sebesar -0,192,320, dapat diartikan jika variabel independen lain nilainya tetap dan nilai variabel rasio efektivitas mengalami kenaikan sebesar 1, maka harga saham akan mengalami penurunan sebesar -0,192,320. Koefisien bernilai negatif antara rasio efektivitas dengan pertumbuhan ekonomi. Jadi kenaikan rasio efektivitas (X1) mengakibatkan penurunan pada pertubuhan ekonomi (Y).”

c. Koefisien regresi variabel rasio efisiensi (X2) sebesar 133,368, dapat diartikan jika variabel independen lain nilainya tetap dan nilai variabel rasio efisiensi mengalami kenaikan 1, maka pertumbuhan ekonomi akan mengalami peningkatan sebesar 133,368. Koefisien bernilai positif antara rasio efisiensi (X2) dengan pertumbuhan ekonomi (Y). Jadi kenaikan rasio efisiensi(X2) mengakibatkan kenaikan pada pertumbuhan ekonomi (Y).

\section{Koefisien Determinasi}

Berikut rumus untuk mencari koefisien determinasi adalah:

$$
K d=\mathrm{R}^{2} \times 100 \%
$$

Tabel 6. Hasil Koefisien Determinasi

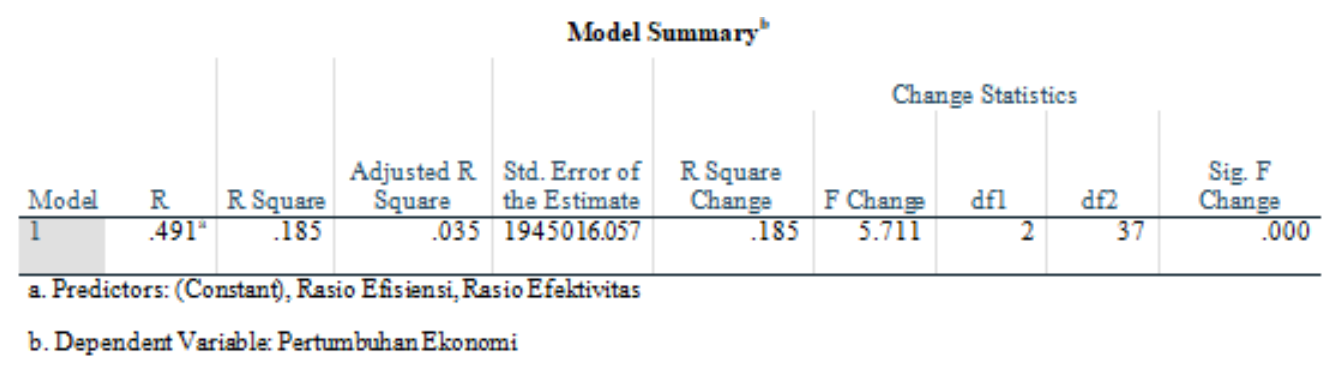

\section{Sumber: Hasil Pengolahan Data Dengan IBM SPSS Statistics 25}

Artinya bahwa kontribusi persentase pengaruh rasio efektivitas dan rasio efisiensi terhadap pertumbuhan ekonomi adalah sebesar $18,5 \%$ sedangkan sisanya $81,5 \%$ dijelaskan atau dipengaruhi oleh variabel lain yang tidak diamati dalam penelitian ini.

\section{Pengujian Hipotesis}

\section{Uji T (Parsial)}

Tabel 7. Tabel Ringkasan Hasil Uji T (Parsial) 


\begin{tabular}{|l|l|l|l|l|r|c|}
\hline Variabel & $\mathbf{t}_{\text {thitung }}$ & $\mathbf{t}_{\text {tabel }}$ * & Nilai & $\boldsymbol{\alpha}$ & Yang & Hipotesis \\
\hline X1: Rasio \\
Efektivitas
\end{tabular}

\section{Sumber: Hasil Pengolahan Data Dengan IBM SPSS Statistics 25}

Berdasarkan uraian pada tabel diatas maka dapat disimpulkan bahwa pengujian variabel Rasio Efektivitas $(X 1)$ dengan $t_{\text {hitung }}(-1,647)>t_{\text {tabel }}(-1,687)$ dan nilai sig $(0,108)>$ $(0,05)$, karena $-t_{\text {hitung }}>-t_{\text {tabel }}$ dengan nilai sig $>0,05$ yang berarti secara parsial variabel Rasio Efektivitas (X1) tidak memiliki pengaruh signifikan terhadap pertumbuhan ekonomi (Y). Maka Ho diterima, Ha ditolak, yang artinya bahwa tidak terdapat pengaruh rasio efektivitas terhadap pertumbuhan ekonomi pada pemerintah kota/kabupaten di Riau.

\section{Uji F (Simultan)}

Tabel 8. Tabel Ringkasan Hasil Uji F (Simultan) 


\begin{tabular}{|c|c|c|c|c|c|c|}
\hline Variabel & $F_{\text {hitung }}$ & $F_{\text {tabel }^{*}}$ & $\begin{array}{c}\text { Nilai } \\
\text { sig }\end{array}$ & $\begin{array}{c}\alpha \\
(5 \%)\end{array}$ & Hipotesis & $\begin{array}{c}\text { Yang } \\
\text { Diterima }\end{array}$ \\
\hline $\begin{array}{l}\text { X1: Rasio } \\
\text { Efektiitas dan } \\
\text { X2: Rasio } \\
\text { Efisiensi }\end{array}$ & 5,711 & 3,25 & 0,000 & 0,05 & $\begin{array}{l}\text { 1. Ho: Tidak terdapat pengaruh } \\
\text { rasio efeltivitas dan rasio } \\
\text { efisiensi terhadap pertumbuhban } \\
\text { eksnomi pada pemerintah } \\
\text { keta/kabupaten di Riau, } \\
\text { 2. Ha : Terdapat pengaruh rasio } \\
\text { efektivitas dan rasio effisiensi } \\
\text { terhadap pertumbuhan ekonomi } \\
\text { pada pemerintah kota/kabupaten } \\
\text { di Riau, }\end{array}$ & $\mathrm{Ha}$ \\
\hline
\end{tabular}

Sumber: Hasil Pengolahan Data Dengan IBM SPSS Statistics 25

Dari hasil analisis data diperoleh $F_{\text {hitung }}(5,711)$, sedangkan $F_{\text {tabel }}(3,25)$ dengan nilai sig 0,000 yang berarti secara simultan atau bersama-sama variabel rasio efektivitas dan rasio efisiensi berpengaruh signifikan terhadap variabel Harga Saham. Dikarenakan $F_{\text {hitung }}(5,711)>F_{\text {tabel }}(3,25)$ dengan nilai sig $(0,000)<0,05$ yang berarti bahwa secara bersama-sama (simultan) variabel rasio efektivitas dan rasio efisiensi berpengaruh signifikan terhadap harga saham. Maka Ho ditolak, Ha diterima, yang artinya bahwa terdapat pengaruh rasio efektivitas dan rasio efisiensi terhadap pertumbuhan ekonomi pada pemerintah kota/kabupaten di Riau.

\section{PEMBAHASAN}

\section{Pengaruh Rasio Efektivitas Terhadap Pertumbuhan Ekonomi Pada Pemerintah Kota/Kabupaten di Riau}

Berdasarkan hasil pengujian secara parsial menunjukkan bahwa nilai $-\mathrm{t}_{\text {hitung }}$ untuk variabel rasio efektivitas adalah sebesar $-1,647$ dan $-t_{\text {tabel }}$ sebesar $-1,687$, sehingga $-t_{\text {hitung }}$ lebih besar dari pada $-t_{\text {tabel }}(-1,647>-1,687)$, karena $-t_{\text {hitung }}>-t_{\text {tabel }}$ maka Ho diterima dan Ha ditolak. Artinya tidak terdapat pengaruh signifikan antara rasio efektvitas terhadap pertumbuhan ekonomi.

Hal berikut bisa disebabkan karena realisasi dengan targetnya masih belum maksimal bahkan terdapat beberapa kabupaten yang tidak mencapai target yang telah ditetapkan sehingga realisasi dibandingkan dengan target maka akan tidak efektif. Menurut teori Mahmudi (2016) apabila nilai rasio efektivitas 100\% - >100\% maka dapat dikatakan efektif tetapi apabila kurang maka nilai tersebut tidak efektif, dilihat dari nilai rata-rata rasio efektivitas sebesar 73,99 yang artinya tidak efektif, dan juga bisa dilihat dari kondisi ekonomi pada saat tahun 2017 rasio efektivitasnya menurun yang apabila dilihat dari tabel kriteria rasio efektivitas $<75 \%$ artinya tidak efektif . 
Kemudian hasil penelitian ini juga sejalan dan diperkuat oleh penelitian terdahulu yaitu (Greydi Normala sari, Paulus Kindangen, Tri Oldy Rotinsulu, 2016) yang menyatakan bahwa rasio efektivitas tidak berpengaruh terhadap pertumbuhan ekonomi.

\section{Pengaruh Rasio Efisiensi Terhadap Pertumbuhan Ekonomi Pada Pemerintah Kota/Kabupaten di Riau}

Berdasarkan hasil pengujian secara parsial menunjukkan bahwa nilai thitung untuk variabel rasio efesiensi adalah sebesar 3,689 dan $t_{\text {tabel }}$ sebesar 1,687, sehingga $t_{\text {hitung }}$ lebih besar dari $t_{\text {tabel }}(3,689>1,687)$, karena $t_{\text {hitung }}>$ dari $t_{\text {tabel }}$ maka Ho ditolak, Ha diterima.

Karena Ha diterima, artinya terdapat pengaruh rasio efesiensi terhadap pertumbuhan ekonomi pada pemerintah kota/kabuaten diRiau Hasil penelitian ini juga diperkuat oleh penelitian (Greydi Normala sari, Paulus Kindangen, Tri Oldy Rotinsulu, 2016), yang menyatakan bahwa rasio efesiensi berpengaruh terhadap pertumbuhan ekonomi.

\section{Pengaruh Rasio Efektivitas dan Rasio Efesiensi Terhadap Pertumbuhan Ekonomi Pada Pemerintah Kota/Kabupaten di Riau}

Hasil uji simultan (F) menyatakan bahwa nilai $F_{\text {hitung }}$ sebesar 5,711 dengan dk pembilang $=2$ dan $\mathrm{dk}$ penyebut $=40-2-1$ dimana tingkat signifikan 5\%, maka didapat $\mathrm{F}_{\text {tabel }}$ sebesar 3,25. Sehingga $F_{\text {hitung }}$ lebih besar dari pada $F_{\text {tabel }}(5,711>3,25)$. Artinya, apabila Fhitung $>$ Ftabel maka Ho ditolak dan Ha diterima. Oleh karena itu, karena Ha diterima maka, artinya terdapat pengaruh rasio efektivtas dan rasio efesiensi secara simultan terhadap pertumbuhan ekonomi pada pemerintah kota/kabupaten di Riau.

Hal ini sesuai dengan teori (Mahmudi, 2016) yang menyatakan bahwa semakin efektif dan efesien suatu daerah, jika pemerintah dapat menggunakan PAD sesuai yang ditargetkan makan hasilnya akan lebih efektif dan teori (Keynes,2017) yang menyatakan bahwa pengeluaran pemerintah mempengaruhi pertumbuhan ekonomi.

Hasil penelitian ini juga diperkuat oleh penelitian terdahulu yaitu (Kartika Berliani, 2016), yang menyatakan bahwa kinerja keuangan pemerintah daerah secara bersama-sama berpengaruh terhadap pertumbuhan ekonomi. (Syamsudin, Bayu Tri Cahya, Syahrina Nurmala Dewi, 2017), yang menyatakan bahwa rasio efektivitas dan rasio efesiensi berpengaruh terhadap pertumbuhan ekonomi.

\section{KESIMPULAN DAN SARAN}


Berdasarkan penelitian yang telah dilakukan mengenai tentang ada tidaknya pengaruh kinerja keuangan pemerintah daerah terhadap pertumbuhan ekonomi pada pemerintah kota/kabupaten di Riau maka dapat disimpulkan sebagai berikut:

1. Perkembangan rasio efektivitas dan rasio efisiensi mengalami kenaikan dan penurunan disetiap tahunnya, ada yang menunjukkan kenaikan dan penuruannya. rasio efektivitas memiliki nilai minimum sebesar 47,28 dan nilai maksimumnya sebesar 149,67, sedangkan rasio efisiensi memiliki nilai minimum sebesar 87,07 dan nilai maksimumnya sebesar 135,31.

2. Perkembangan pertumbuhan ekonomi disetiap tahunnya mengalami penaikan dan penurunan, ada yang menunjukkan kenaikan dan penuruannya signifikan adapun yang tidak signifikan. Pertumbuhan ekonomi memiliki nilai minimum sebesar 1.145.007 dan nilai maksimumnya sebesar 8.057.698.

3. Hasil uji hipotesis secara simultan antara variable (X1) Rasio Efektivitas (X2) Rasio Efisiensi terhadap variabel (Y) Pertumbuhan Ekonomi menunjukkan bahwa terdapat pengaruh antara Kinerja Keuangan Pemerintah Daerah Terhadap Pertumbuhan Ekonomi pada Pemerintah Kota/Kabupaten di Riau.

Berdasarkan kesimpulan diatas, penulis mencoba memberikan saran yang dapat memberikan manfaat bagi peneliti selanjutnya. Adapun saran tersebut adalah sebagai berikut:

1. Peneliti selanjutnya yang tertarik untuk meneliti lebih lanjut dengan tema yang sama yaitu Akuntansi Sektor Publik, disarankan untuk memperbaiki kekurangan-kekurangan yang terdapat didalam penelitian ini."

2. Penelitian selanjutnya diharapkan dapat menambahkan sampel yang digunakan dan memperluas penelitian bukan hanya 10 pemerintah daerah saja sehingga hasil data yang lebih baik.

3. Bagi peneliti selanjutnya yang akan melakukan penelitian selanjutnya, penulis menyarankan agar peneliti dapat menambahkan atau merubah variabel-variabel lainnya yang dapat mempengaruhi pertumbuhan ekonomi.

\section{DAFTAR PUSTAKA}

Agustina dalam Pramita 2015 Analisis Rasio Untuk Menilai Kinerja Keuangan Daerah Kabupaten Kebumen Tahun 2009-2013. Jurnal Ekonomi.

Goriau.com. 2020 Pertumbuhan Ekonomi Riau Terendah di Pulau Sumatera [internet].(https://www.goriau.com/berita/baca/pertumbuhan-ekonomi-riauterendah-di-pulau-sumatera.html) diakses pada (10 Februari 2020) 
Greydi, Paulus dan Tri Oldy 2016. Pengaruh Kinerja Terhadap Pertumbuhan Ekonomi Perkotaan di Sulawesi Utara Tahun 2004-2014. Jurnal Pembangunan Ekonomi dan Keuangan Daerah Vol. $18, \quad$ NO. 2. (https://ejournal.unsrat.ac.id/index.php/jpekd/article/view/12789 diakses: 2 Juni 2020)

Kartika, Beliani. 2016 Pengaruh Kinerja Keuangan Terhadap Pertumbuhan Ekonomi dan Implikasinya Terhadap Kesejahteraan Masyarakat Kabupaten Majalengka. Jurnal Indonesia Membangun ISSN: 1412-6907 Vol. 2, No. 1. Mei-Agustus2016. (https://jurnal.inaba.ac.id/index.php/JIM/article/download/70/65 diakses: 2 Juni 2020)

Kawatu, F.S 2019 Analisis Laporan Keuangan Sektor Publik. Penerbit Buku Pendidikan Deepublish.

Mahmudi. 2015 Analisis Laporan Keuangan Pemerintah Daerah. Yogyakarta: Edisi Kedua. UPP STIM YKPN,

Muhhamad Syukri, Hinaya 2019 Pengaruh Pertumbuhan Ekonomi, Pendapatan Asli Daerah, Dana Alokasi Umum dan Dana Alokasi Khusus Terhadap Anggaran Belanja Modal, Kabupaten dan Kota Provinsi Sulawesi Selatan. Journal Of Economic, Management and Accounting Vol. 2, No. 2. Fakultas Ekonomi Universitas Andi Djemma (http://www.ojs.unanda.ac.id/index.php/jemma/article/view/245 diakses pada 2 Juni 2020)

Mardiasmo, 2017. Akuntansi Sektor Publik. Yogyakarta: Penerbit Andi

Sugiyono. 2017 Metode Penelitian Kuantitatif, Kualitatif dan R\&D. Bandung: Alfabeta, $\mathrm{Cv}$

Sukirno, Sadono 2015 Ekonomi Pembangunan Jakarta: Edisi Kedua. Kencana,

Syamsudin, Bayu Tri dan Syahrina Nurmala 2016 Pengaruh Kinerja Keuangan Terhadap Pertumbuhan Ekonomi, Pengangguran dan Kemiskinan. Fakultas Ekonomi dan Bisnis. Universitas Muhammadiyah Surakarta. (http://journals.ums.ac.id/index.php/dayasaing/article/view/2271 diakses: 2 Juni 2020)

Undang-Undang No.23 Tahun 2014 (https://peraturan.bpk.go.id/Home/Details/38685/uuno-23-tahun-2014 diakses: 2 Juni 2020) 